\title{
Analysis of philosophy and humanization art relationship in the first decade of the $X X$ century
}

\author{
Alla Matveeva*, Roman Krasnov, Elena Atmanskykh, and Regina Zaynetdinova \\ Ural State University of Economics, 620144, Yekaterinburg, Russia
}

\begin{abstract}
When writing the article, the authors pursued one goal: to understand why extreme subjectivity in art, the abandonment for centuries of setting traditions, laws and techniques in art led to the loss of aesthetic criteria by the modernism art, and what philosophical trends influenced this process. The methodological basis of the article is the principles of integrity, objectivity and historicism. The following methods were applied: historical and philosophical analysis, focused on the objective completeness of the study; cultural and comparative approaches aimed at establishing spiritual ties between artists of different historical eras. The article analyzes the works of philosophers and artists, such as: Bergson, Schopenhauer Nietzsche, Chirico, Apollinaire, Lenin, Bru, Kandinsky. Various directions of bourgeois art are considered. The authors believe that abstract art, fully antisocial and dehumanized, fully meets the aesthetic ideals of the modernism art, which opposed itself to human from its very birth. The authors argue that if you take the artists' position of that time, you can make an unambiguous conclusion, the dehumanization of art could not be avoided. According to the authors, abstract art, fully antisocial and extremely dehumanized, is fully consistent with the goals of bourgeois ideologists and fully meets the aesthetic ideals of the art of modernism, which has opposed itself to man since its inception.
\end{abstract}

\section{Introduction}

At the beginning of the XXI century, scientists are increasingly arguing about how there is a connection between philosophy and art. Throughout the centuries, philosophy, art has gone hand in hand, although many artists believed that philosophy should master intuition, having previously learned to use the instinct correctly: "If the consciousness dormant in it wakes up, if it were to go inside, to know, instead of to go outside, into action, if they knew how to ask him and if he could answer us, he would reveal to us the innermost secrets of life" (Bergson, 1914, p.149).

The article provides an analysis of the relationship between philosophy and the dehumanization of art in the first decade of the XX century, just then the mission of bringing philosophy closer to art should be performed by art: "Can such critics of known critics ever compare with a pencil stroke of a great artist?" (Bergson, 1914, p.214) - asks

\footnotetext{
*Corresponding author: matveevaa2011@yandex.ru
} 
Bergson. Here it should be noted that, speaking about the role of instinct and intuition in the cognition of the life process, Bergson emphasizes that they should not be connected with reality, with the objective world, but should be sent "inside" to a special world.

In our opinion, philosophy is precisely this special world, many still not understood and unattainable, a world of abstraction and reflection and always relevant for study.

\section{Wording of the problem}

When writing the article, the authors pursued one goal: to understand why extreme subjectivity in art, the abandonment of centuries of traditions, laws and techniques in art led to the loss of aesthetic criteria by the art of modernism, and what philosophical trends influenced this process.

\section{Research methods}

The methodological basis of the article is the principles of integrity, objectivity and historicism. The following methods were applied: historical and philosophical analysis, focused on the objective completeness of the study; cultural and comparative approaches aimed at establishing spiritual ties between artists of different historical eras.

\section{Cases and their research}

Similarly, art should not be connected with the real world. This thesis was formulated by Bergson in his work "Laughter in life and on stage", dedicated to specific problems of art and artistic creation: "What is the subject of art? If reality acted directly on our feelings and our consciousness, if we could enter into direct communication with things and ourselves, then art, I think, would then be useless, or, rather, we would all be artists, because our souls would vibrate in harmony with nature "(Bergson, 1900, p. 138). Bergson's juxtaposition of the reality art and the artistic creation of intellect, as well as his idea of the elitism of art and the election of his figures, all formed the basis of the modern artists' worldview of the most diverse trends and interpretations. Intuitionism was not the only philosophical movement that influenced the art of modernism. Such a theory was for the figures of bourgeois art the teachings of F. Nietzsche (Kulikova, 1974, p. 51). Following Schopenhauer (with whom Nietzsche's early stage as a philosopher was connected), Nietzsche emerges as an irrationalist who sees in the intellect the main obstacle to the merging of man with the world, with "life" (Melman, 1960, p. 28). The path to a "holistic man," according to Nietzsche, lies through the "reappraisal of all values" of traditional culture (Kulikova, 1974, p. 52). Nietzsche's ideal of "an integral human" is the "superman", free in his instinctive impulses from any moral restrictions, as well as from the power of objective laws (Heer, 1962, p, 61). He creates his truth, creates his "good." In this regard, Nietzsche interprets art as a sublimation of sensual pleasure, "I am aesthetic pleasure" - as a result of mixing essential human instincts excited in the process of perceiving a work of art (Orlega y Gasset, 1950, p. 81.).

Futurism as a direction of modernist art manifested itself in 1909, a year after the first exhibition of cubist paintings in Paris (Kulikova, 1974, p. 51). Futurists claimed that movement and light supposedly destroy the materiality of bodies and that only an artist in his work can show movement. They called themselves "primitives of a new feeling" and boasted that they were torn off; from material reality, art is "intoxicated by arbitrariness and power." Defending themselves against completely thorough attacks on their art, which represented life in the form of crazy chaos, the futurists declared: "We must recognize the 
honorary name for the nickname "crazy", which innovators try to shut up their mouths" (Murno, 1960, p. 89). Like the Cubists, the futurists believed that a work of art should not reflect reality.

The socio-aesthetic ideals of the futurists were also built on Nietzschean foundations; after the futuristic "revaluation of values", the "Art of the Future" was to be built on the debris and ruins of the old, centuries-old accumulated human culture (Manifestos of Italian Futurism, 1914, p.6). As a "positive" hero of the century - the century of imperialism, the futurists cultivated a "mechanical human with replaceable parts" this "human" surprisingly resembled the "superman" Nietzsche, speaking of his "ideal hero", the futurists, like Nietzsche, denied the need for him to or moral standards, considered the basic and natural right of the individual - the right of the strong (Manifestos of Italian Futurism, 1914, p. 35).

"A person seeks to pollute with his young joy or his aging sorrow material that is neither young nor old ..." (Murno, 1960, p. 110). They proposed to expel all human feelings and emotions from art and literature - a person is completely corrupted by the library and the museum, subordinated to terrifying logic and wisdom and is now of no interest. Futurism as a direction in art disintegrated at the beginning of the First World War.

In contrast to futurism in Italy in the same pre-war years, a direction or as they often call it a school of "metaphysical" painting arose. Its founder was the Italian artist Giorgio de Chirico, who declared himself in 1910 by participating in the exhibition of the Independents in Paris. During his studies in Munich, Chirico became acquainted with the works of Nietzsche, Schopenhauer. Weininger. Chiriko made an attempt to embody the abstract metaphysical ideas of idealist philosophers by means of painting. According to bourgeois scholars, Chirico's works were intended to reflect the "pathos of Zarathustra" (Jullian, 1966, p. 126). However, Chiriko's painting, rather, testifies to the influence of Schopenhauer's philosophy on him: the artist seems to be trying to express the "idea" of phenomena and things, something that goes beyond reality. The deliberate "significance" is given to Kiriko's paintings by a detailed perspective, elongated horizon lines. Static monumentality is achieved by a clear arrangement of objects at right angles to the horizon. Despite the geometrically clear construction, Chiriko's paintings give the impression of a maze.

Chiriko's paintings claiming epicness defy logical perception and explanation, although Chiriko contrasts his work with the work of modern artists, there is no fundamental difference between his creative method and the creative method of cubists and futurists: Chiriko uses the method just like them formalism, the ideological basis of Chiriko's activity is idealistic philosophy, which denies the need to reflect reality in artistic creation ((Jullian, 1966). Just like cubism and futurism, the "metaphysical" art of Chiriko turned out to be hopeless and quickly, already at the end of the First World War, exhausted itself.

Thus, the rethinking that began in 1905; artistic creation led to a change in artistic techniques and method, with the result that in the early 1910s: the so-called modernist art arose. Theorists and practitioners of the modernism art have radically changed the nature (goals, objectives, techniques) of artistic creation. These changes were mostly negative, and as a result, art lost those qualities that were still considered to be inherent in it. First of all, the "real, material world" ceased to be an object of art and philosophy. This led to the disappearance of the imagery from works of art, which amounted up to XX.

Extreme subjectivity in art, the rejection of centuries of setting traditions, laws and techniques in art led to the loss of aesthetic criteria by the art of modernism. If works of art do not correlate with life, if they do not have a generally understood content, and with their help the artist does not transmit his understanding of the world to the audience, if the works of art are extremely subjective and are the product of the artist's intuition, then this art cannot be considered on the basis of objective criteria, cannot be evaluated on the basis of the general laws of artistic creation. The works of such art obviously do not meet the 
requirements for art as a form of social consciousness, and in some cases even go beyond the scope of artistic creation itself.

At the beginning of the XX century bourgeois theorists of artistic culture declared dehumanization one of the main features of the modernism art, one of the main tasks of the contemporary artists' work (Kulikova, 1974, p. 63). "First of all, artists are people who want to become inhuman," G. Apollinaire wrote in 1913 in his book Cubist Artists (Roger Shattuck, 1961, p. 268.). They painfully search for traces of inhumanity, traces that are not found in nature." A similar point of view was shared by the Spanish bourgeois philosopher and art theorist José Ortega y Gasset, in his work "Dehumanization of Art" (Madrid, 1925). The very definition of abstract art implicitly contains its sharp contrast to realistic art.

Nothing from the real world that surrounds us needs to be prevented by our own imagination from discovering subjects completely unrelated to the artist's intentions, similar to those images that everyone manages to see in the clouds. An abstract artist should strive to avoid, as far as possible, such fruitful meetings for figurativeness, but of course, he cannot be held responsible for the imagination of the audience. "Having refused the abstract artist the right to turn to life as an object of art in his work, abstract theoreticians proclaim art in accordance from the norms of the formalistic method of "the thing in itself." Subjecting to criticism the philosophical category of "things in themselves", V. I. Lenin wrote: "Any mysterious, tricky, ingenious difference between a phenomenon and a thing in itself is continuous philosophical nonsense. In fact, each person millions of times has observed the simple and obvious the transformation of "things in themselves" into a phenomenon, "a thing for us" (Lenin, 1967, p. 120).

By manipulating the concept of "things in themselves", theorists of bourgeois art strive to give abstractionism hidden from the uninitiated, esoteric: a meaning that, of course, does not exist in abstract art. The founder of abstractionism is the Russian artist V. Kandinsky, who lived and worked mainly abroad. The first work of abstractionism is considered watercolor, painted by him in 1910 in Munich. "For the first time in the history of painting, it was impossible to notice or recognize anything in the picture," writes French critic S. Bruh about this work in his book "The Aesthetics of Abstract Art". The appearance of abstract painting theorists of art explains in different ways. Bru says that V. Kandinsky came up with this idea when he accidentally leaned one of his paintings against the wall sideways: the image in the painting became incomprehensible - only the colors mysteriously flashed (Bru, 1959, p. 3).

The ground for the introduction of abstractionism was already prepared by cubists and futurists, who violated in their works the principle of matching the content and form of an artwork with objects and phenomena of real life. Abstract art brought to an end the destruction of the form and content of a work of art begun by cubism and futurism. If separate signs, details, features of objects and people are still preserved in the paintings of cubists and futurists, then in the abstract paintings and sculptures these signs are already completely absent.

Kandinsky linked the direction he created with idealistic philosophy and clearly contrasted "abstractionism with materialism". In his very first "theoretical" work, written in the same 1910 (first published in German in late 1911), Kandinsky defines his initial philosophical positions: "The Spirit Leading into the Kingdom of Tomorrow", maybe known only by feeling. The artist's talent paves the way there" (Kandinsky, 1967, p. 36). Kandinsky appeals to the authority of prominent scientists, scientists, who, "with their passionless work" allegedly "call into question the very matter on which everything rested yesterday and on which the whole universe rested."

Kandinsky declared the path of abstractionism by saving a person who is allegedly under the "nightmare of materialistic worldviews" (Kandinsky, 1967, p. 37). 
Kandinsky directly warned against attempts to transfer forms of characteristic music expression that realizes itself in time, has duration in the field of painting, devoid of this property. The followers of Kandinsky did not heed his warnings and spent a lot of fruitless time and effort,

Offering his method of form-creation, Kandinsky nevertheless found that "an artist cannot do without purely abstract forms. For him, these forms are too inaccurate. To limit oneself only to inaccurate means to deprive oneself of many opportunities, to exclude the purely human and make the means of expression poor" (Kandinsky, 1967, p. 64). Kandinsky underestimated the "possibilities" and the internal logic of the art direction he invented: namely, the creation of abstract geometric forms devoid of "purely human". Kandinsky pointed out the real dangers awaiting artists on the path to abandoning imagery.

Modern artists have not escaped these dangers: senseless geometrization formed the basis for a number of abstractionism areas, the aimless play of color and bizarre forms for illogical fiction has been absorbing the power of surrealist artists for many years.

\section{Conclusion}

In this article, we examined only a small part of the trends of art developing in the first decade of the twentieth century and philosophical movements influencing their development. The authors would like to conclude this article with an analysis of the work of Kandinsky, since the negative, warning arguments of Kandinsky, who had passed through the solid school of realistic artistic creativity until 1910, are quite thorough and convincing. Kandinsky is weak and helpless in his "positive" program for freeing art from the "oppression" of the real and reducing it to form-creation.

Offering to abandon the display of life by means of art, Kandinsky recommends that artists pay special attention to the fact that the forms sought and found by them are deprived of the subject, even of the most unnatural "fairy-tale" form, Kandinsky explains, will make viewers search for the subject, make them immune to pure action colors", "to strong spiritual vibrations" (Kandinsky, 1967, p.128). Form and colors, Kandinsky emphasizes, should not cause any external or related narrative action. An artist should draw abstract forms not from nature, but "from within." Putting his theory into practice, Kandinsky creates abstract works of three types of impression, improvisation and composition, equally devoid of meaning, unrelated to life, non-communicative. Geometrization formed the basis for a number of abstract art areas; the aimless play of color and bizarre forms of illogical fiction has been absorbing the power of surrealist artists for many years.

The negative, warning arguments of Kandinsky, who had gone through a solid school of realistic artistic creativity until 1910, are thoroughly convincing. Kandinsky is weak and helpless in his "positive" program for freeing art from the "oppression" of the real and reducing it to form-creation.

In 1913, as part of abstract art; Suprematism arose. The initiator of this trend was the Russian artist K. Malevich. Suprematists declared their task the expression of the pure feeling superiority, embodied for the sake of maintaining its purity without the help of any appeal to the outside world, exclusively using planar geometric shapes. The first work of Suprematism is considered to be "Black Square on a White Background" by K. Malevich. But this plane was not the last, after five years. Malevich declared this work the culmination of Suprematism, explaining that it does not create the actual squares, but the very "expression of pointlessness" (Malevich, 1919, p. 32), reveals: the superiority of "pure feeling" with planar geometric figures. The audience, confusedly standing in front of the picture, was completely unpleasant, in what is expressed, it turns out "only on the principle of an expedient touching of the human soul." He believed that the main task of art "psychic power of paint" to cause "mental vibration". Malevich again believed intuitionism: 
"Intuition pushes the will to creativity, and in order to reach it, you need to get rid of the objective, you need to create new signs, reaching the complete annulment of objectivity in art, we will take the creative path of creating a innovation, we will avoid any juggling on the wire of art with different objects, with which they are now practicing and striving to pull up ", and the schools of fine art," read Malevich (Malevich, 1919, p. 30).

If we take the position of artists of that time, we can make an unambiguous conclusion that the dehumanization of art could not be avoided. In our opinion: abstract art, fully antisocial and extremely dehumanized, is fully consistent with the goals of bourgeois ideologists and fully meets the aesthetic ideals of the art of modernism, which has opposed itself to man from its very inception.

\section{References}

1. A. Bergson, Creative evolution (M.- St. Petersburg, 1914).

2. A. Bergson, Laughter in life and on stage (St. Petersburg, 1900).

3. I. Kulikova, The philosophy and art of modernism (Politizdat, Moscow,1974).

4. S. Melman, The Peace Rase (London, 1960).

5. F. Heer, Offener Humanismus (Berlin - Stuttgart - Wien, 1962).

6. Jose Orlega y Gasset. La deshumanizacion del arte (Obras Completas, t. III, Madrid, 1950).

7. Th. Murno. The Marxist Theory of Art History. Socio-economic Determinism and Dialectical Process, The Journal of Aesthetics and Art Criticism, 4, (1960).

8. R. Jullia, Le futurism et la peinture italienne (Paris, 1966).

9. Roger Shattuck, The Banquet Years: the arts in France, 1885-1918: Alfred Jarry, Henri Rousseau, Erik Satie, Guillaume Apollinaire (Doubleday, 1961).

10. V.I. Lenin, Full Coll of works, V. 18 (Publishing house of "Political Literature", Moscow, 1967).

11. Ch. Bru, Esthetique de l "abstraction (Paris, 1959).

12. K. Malevich, About new systems of art (Vitebsk, 1919). 